\title{
Menyingkap Situs "Koto Rayo", Pemukiman Kuno di Tepi Sungai Tabir Jambi
}

\author{
Pahrudin \\ Universitas Gadjah Mada
}

Sumatra Island have high civilization in the past, especially through The Kingdom of Sriwijaya that controled and dominated all around this island and most of South East Asia territories. One area of the Kingdom Sriwijaya's territory in Sumatra Island is Jambi, that have many Kingdoms of Melayu before. 'Koto Rayo' that located at side of Tabir River may be one of the civilization that connected with history of Kingdoms of Melayu Jambi and Kingdom of Sriwijaya in the past. Because, the remnants of the past about Koto Rayo, like red bricks, are very resemble with red bricks of temple in other area at Jambi (Muaro Jambi Temple) and many stories about this site are connected with history of Jambi in the past.

This article discusses about 'Koto Rayo', an ancient settlement at side of Tabir River. This site has been kept secret of Jambi and history that haven in this area in the past.

Kata Kunci: Sumatra, Sriwijaya, Melayu, Jambi, Civilization, Koto Rayo.

\section{Pengantar}

Sumatera adalah salah satu pulau terbesar yang ada di kepulauan Nusantara yang kini dikenal dengan Indonesia. Di masa lalu, Pulau Sumatera dikenal dengan banyak nama, bahkan nama-nama tersebut kadang-kadang masih digunakan hingga saat ini. Pulau yang terletak di bagian barat Indonesia ini juga dinamakan "Swarna Dwipa" yang berarti "pulau emas" karena diyakini memiliki kandungan emas yang melimpah atau bisa juga karena beragam sumberdaya (resources) yang dimilikinya layaknya emas yang sangat berharga, kadang juga dikenal dengan nama "Andalas" yang tidak diketahui asal usul nama tersebut. Akan tetapi, nama resmi yang biasa digunakan adalah Sumatera. Wilayah ini memiliki beragam sumberdaya (resources), baik berupa bahan tambang seperti emas dan perak juga berupa alamnya yang memiliki berjutajuta hektar lahan yang ditumbuhi pepohonan serta perkebunan (terutama karet dan kelapa sawit) yang seakan memenuhi setiap jengkal tanah yang ada di pulau ini. Di samping beragam sumberdaya di atas, Sumatera juga memiliki resources lain yang tak kalah urgensitasnya, yaitu peradaban masa lalu yang pernah berjaya di pulau ini.

Menyebut peradaban masa lalu Sumatera tentu tidak bisa dilepaskan dari sebuah kerajaan besar yang pernah menguasai beragam wilayah di Indonesia dan Asia Tenggara, Kerajaan Sriwijaya. Salah satu kerajaan Hindu terbesar di Nusantara ini memang berpusat di Pulau Sumatera, meskipun pusat kekuasaannya masih diperselisihkan. Ada yang mengatakan berada di Jambi karena berdasarkan penelitian yang dilakukan Prof. Slamet Muljana, letak geografis Jambi yang langsung berhadapan dengan laut lepas lebih cocok untuk menetapkan wilayah ini sebagai pusat Kerajaan Sriwijaya. Di samping bukti-bukti arkeologis lebih banyak ditemukan di wilayah ini, juga karena Sriwijaya sebagai kerajaan maritim dan perdagangan lebih memungkinkan untuk dilalui oleh kapal-kapal besar dari berbagai wilayah di Asia Tenggara yang menjadikan Selat Malaka sebagai pusatnya saat itu dibandingkan Palembang yang terbentur oleh Selat Bangka yang hanya dilalui oleh kapal-kapal kecil dari dan menuju Jawa. Prof. Muljana juga memaparkan berita-berita dari Arab yang mengatakan adanya Maharaja dari Zabag yang dapat diidentifikasi sebagai Muara Sabak yang berada di ujung Semenanjung Jambi (Kabupaten Tanjung Jabung sekarang) dan menjadi pintu masuk bagi kapal-kapal yang menuju Jambi dan laut lepas. Atau dari berita China yang mengatakan nama San-fo-ts'i sebagai kawasan penting dalam Sriwijaya saat itu dan dapat diidentikkan dengan (Muara) Tembesi yang 
ada di Jambi saat ini (Muljana, 2008: 107-119). Ada pula yang mengatakan berpusat di Riau berdasarkan kesimpulan Ir. Moens yang mengatakan bahwa Kerajaan Sriwijaya lama berpusat di sebuah Semenanjung karena berdasarkan berita-berita China dan Arab (Abu Zaid), pusat kerajaan ini berhadap-hadapan dengan Tiongkok. Pada saat itu, di Palembang memang sudah ada sebuah kerajaan tetapi dikalahkan dan akhirnya mendirikan kerajaan di wilayah Melayu, yaitu di Muara Takus, dekat tempuran Kampar Kanan dan Batang Mahat atau di Riau saat ini (Muljana, 2008: 105-106). Akan tetapi pendapat umum para sejarawan yang berdasarkan beberapa bukti arkeologis mengatakan bahwa Kerajaan Sriwijaya berpusat di Palembang. Pendapat ini sebenarnya lebih karena berdasarkan adanya Prasasti Telaga Batu Palembang yang berhubungan dengan Sriwijaya. Namun demikian, menurut Muljana, jika prasasti tersebut diteliti dengan seksama maka akan ditemukan kesimpulan sebaliknya. Prasasti tersebut sebenarnya adalah semacam peringatan bagi Palembang yang telah ditaklukkan oleh Sriwijaya yang berpusat di Jambi untuk menjaga ketertiban dan keamanan wilayah tersebut dan bukanlah piagam raja atau negara Sriwijaya. Begitu juga Prasasati Kedukan Bukit Palembang yang sebenarnya adalah suatu hadiah dari raja yang telah menaklukkan wilayah tersebut (Muljana, 2008: 115-116).

Kerajaan yang diperkirakan berdiri antara abad ketujuh sampai abad ketiga belas Masehi ini dalam catatan sejarah Indonesia disepadankan dengan kebesaran Majapahit yang juga pernah menguasai banyak wilayah di Nusantara dan Asia Tenggara dan berpusat di Jawa Timur. Tidak banyak memang bukti arkeologis yang menunjukkan keberadaan Sriwijaya di wilayah Sumatera, kecuali beberapa candi dan batu bertulis serta prasasti yang ada di Jambi, Riau dan Palembang. Itu pun dengan kondisi yang masih kurang lengkap jika dibandingkan dengan bukti-bukti arkeologis yang ditinggalkan oleh peradaban-peradaban yang pernah ada di Jawa. Meskipun demikian, beberapa peninggalan sejarah tersebut cukup dijadikan bukti untuk menetapkan bahwa di Sumatera pernah ada dan berdiri sebuah kerajaan besar yang dapat dikatakan sebagai super power-nya kawasan regional Asia Tenggara saat itu. Salah satu wilayah yang pernah dikuasai oleh Sriwijaya adalah Jambi yang jauh sebelum kerajaan ini berdiri sudah memiliki kedaulatan sendiri melalui tiga kerajaan Melayu Kuno, yaitu: Koying dan Tupo di abad ketiga Masehi serta Kantoli di abad kelima Masehi dan berlanjut kemudian dengan munculnya Kerajaan Melayu Jambi (www.melayuonline.com, 2011 dan www.wikipediaindonesia.com, 2011).

Sedangkan Jambi saat ini adalah sebuah wilayah propinsi yang terletak di bagian tenggara Pulau Sumatera, berbatasan dengan Riau, Bengkulu, Sumatera Selatan dan Sumatera Barat. Sebelum kemerdekaan Indonesia, atau tepatnya pada abad ke sembilan belas, Provinsi Jambi yang dikenal sekarang adalah sebuah kesultanan (Locher-Scholten, 2002: 160).

Karena posisinya yang strategis, maka beragam kekuatan saling bersaing dan berebut untuk dapat menguasai wilayah ini. Mulai dari Kerajaan Melayu Kuno, Melayu Jambi, Sriwijaya dan Singosari dari Pulau Jawa. Beragam kekuatan yang menguasai Jambi tersebut menyisakan peninggalan-peninggalan sejarah yang dapat disaksikan saat ini, seperti Candi Muaro Jambi; patung Adityawarman; Batu Bertulis Karang Brahi dan Patung Amogapacha. Di samping itu, persaingan yang berujung peperangan tersebut juga membuat beberapa komponen kelompok yang kalah melarikan diri dan membangun pemukiman lain yang jauh dari pantauan penguasa. Pemukiman-pemukiman tersebut umumnya berada di daerah pedalaman sungai dalam jarak yang berpuluh-puluh kilometer dari pusat kerajaan seperti salah satunya adalah Koto Rayo.

Tulisan berikut akan mencoba memotret salah satu 'peradaban' yang tersisa dari sejarah masa lalu kerajaan Jambi yang masih dapat disaksikan saat ini. Sebuah paparan yang berisikan analisis penulis mengenai Koto Rayo, sebuah pemukiman kuno di pinggir Sungai Tabir Jambi yang diupayakan dilakukan dalam konteks sejarah dan budaya, khususnya kearifan lokal yang diwariskannya. 


\section{Pemukiman Kuno di Koto Rayo}

Sebagaimana diketahui bahwa di masa lalu sebelum sarana dan prasarana transportasi darat berkembang, sungai menjadi sarana perhubungan utama yang digunakan oleh masyarakat. Jambi yang memiliki banyak sungai, baik besar maupun kecil, juga dimanfaatkan masyarakatnya untuk beragam keperluan. Sungai Batanghari adalah sungai terbesar di Jambi, sekaligus juga di Sumatra, yang memiliki banyak anak-anak sungai seperti Tabir, Merangin, Tembesi dan Batang Bungo. Karena sungai sudah menjadi bagian integral dalam masyarakat Jambi, maka di sepanjang aliran sungai bermunculan banyak pemukiman hingga berkembang menjadi kawasan otonom yang dikemudian hari dikenal dengan munculnya Kerajaan Melayu Jambi.

Sungai Tabir yang berhulu di Danau Kerinci dan bermuara di Sungai Batanghari adalah sarana transportasi utama masyarakat sebelum sarana transportasi darat berkembang pesat di era pasca kemerdekaan. Sungai ini dahulu dapat dilalui oleh kapal-kapal dengan ukuran kecil dan menengah, baik dari hulu maupun hilirnya. Dan di salah satu bagian sungai yang di tepi-tepinya banyak ditumbuhi beragam tumbuhan dan bagian terdalam sungai (lubuk) terdapat Koto Rayo. Berjarak sekitar 10 kilometer di sebelah timur Desa Rantau Limau Manis, atau jika menggunakan kapal dari arah hilir (Kota Jambi) lokasi ini terletak sebelum Desa Rantau Limau Manis, sedangkan jika dari arah hulu maka terletak setelahnya. Posisi Koto Rayo terletak di sebuah bukit bertingkat-tingkat yang menjorok ke sungai dan menyimpan banyak misteri yang belum terpecahkan hingga saat ini dan dianggap keramat oleh masyarakat setempat. Di bukit kecil yang kini banyak ditumbuhi beragam pohon-pohon liar dalam beragam ukuran ini banyak ditemukan batu-batu merah yang berserakan di seantero kawasan seluas sekitar satu setengah hektare itu. Batu-batu bata merah tersebut di samping ditemukan berserakan, juga dapat dijumpai dalam gundukan-gundukan tanah berbentuk piramid kecil yang tersusun dan sepertinya terbentuk secara alami di kawasan ini. Batu-batu bata merah ini sudah penulis bandingkan secara kasat mata dengan batu-batu bata merah yang ada di Candi Muara Jambi. Hasilnya menurut pengetahuan penulis dan beberapa kalangan di Desa Rantau Limau Manis sama atau sangat identik dengan yang ada di salah satu peninggalan masa lalu Jambi tersebut (sebagimana gambarnya terlampir). Benda-benda lainnya yang juga dapat ditemukan di kawasan 'misterius' ini adalah beragam pecahan porselin berupa mangkok dan piring yang berasal dari peradaban masa lalu. Di dalam kawasan ini juga terdapat kuburan yang dianggap keramat oleh masyarakat sekitar, terletak di bawah pohon besar di antara batu-batu bata merah yang berserakan dengan ukuran yang jauh lebih besar dan panjang dibandingkan kuburan pada umumnya.

Menurut cerita yang diberitakan secara turun temurun dan berkembang di tengah masyarakat, Koto Rayo di masa lalu adalah pemukiman masyarakat atau dapat dikatakan sebuah daerah kerajaan kecil yang menguasai wilayah tersebut. Batu-batu bata merah yang banyak banyak ditemukan di lokasi tersebut adalah bangunan candi yang telah hancur, apakah sengaja dirusak atau oleh sebab alami. Saat 'kerajaan kecil' ada, suasana di Jambi dalam keadaan kacau balau karena peperangan yang terjadi antara beragam kekuatan yang hendak menguasai daerah ini. Atas kesepakatan saat itu, Koto Rayo mengirimkan 20 orang terbaik mereka untuk memantau keadaan di muara Sungai Tabir (Sungai Batanghari) dan berjaga-jaga atas kemungkinan adanya musuh yang hendak menyerang mereka. Di muara sungai, kedua puluh orang Koto Rayo tersebut terlibat peperangan dengan musuh sehingga menyebabkan salah seorang di antara mereka terbunuh. Agar tidak menimbulkan korban jiwa yang lebih banyak lagi, maka orang-orang Koto Rayo tersisa memutuskan untuk melarikan diri dan pulang ke tempatnya. Sementara di sisi lain, masyarakat Koto Rayo menganggap kedua puluh orang pilihannya tersebut sudah terbunuh oleh musuh karena tidak ada kabar berita, maka mereka pun memutuskan untuk meninggalkan daerah tersebut dengan cara yang misterius serta tidak diketahui bagaimana cara dan kemanakah mereka mengungsi. Ada pendapat yang mengatakan bahwa mereka memang hilang begitu saja secara misterius, tetapi ada pula yang berkata 
bahwa mereka mengungsi ke wilayah lainnya jauh ke dalam, atau ke tempat yang bernama Muaro Teleh. Para 'pengungsi' yang berasal dari Koto Rayo ini menurut versi cerita yang kedua merupakan asal muasal orang-orang Ulak Makam yang kini menempati sebuah desa yang bertetangga dengan Rantau Limau Manis di sebelah barat. Sementara itu di sisi lainnya, setelah melarikan diri dari peperangan di muara sungai, maka kesembilan belas orang yang tersisa tersebut memutuskan kembali ke Koto Rayo dan mendapati daerah tersebut sudah tidak berpenghuni lagi. Akhirnya mereka memutuskan untuk terus melanjutkan perjalanan lebih ke pedalaman menuju hulu sungai dan menetap di tempat yang kini dikenal dengan Rantau Panjang yang menjadi ibukota Kecamatan Tabir. Penentuan tempat tinggal mereka tidak dilakukan sembarangan tetapi berdasarkan kesamaan lokasi dengan tempat mereka sebelumnya. Penamaan 'Rantau Panjang' dengan daerah hunian baru mereka dilakukan untuk mengelabui musuh yang hendak mencari mereka karena nama ini sebelumnya dipakai untuk menyebut kawasan yang ada di Koto Rayo. Seiring dengan perjalanan waktu, maka lambat laun pemukiman masyarakat semakin menyebar ke hilir di sepanjang tepi Sungai Tabir hingga ke tepi Koto Rayo daerah asal mereka dahulu. Cerita mengenai ke20 orang pilihan yang berasal dari Koto Rayo ini saat ini masih melekat dalam adat istiadat masyarakat yang ada di sepanjang aliran Sungai Tabir, khususnya dari Rantau Panjang di barat (hulu) sampai ke Rantau Limau Manis di timur (hilir). Yaitu, digunakan untuk mengajukan tuntutan hukum mengenai suatu perkara atau permasalahan yang terjadi di masyarakat kepada pemuka adat atau tokoh masyarakat dan biasa dikenal dalam masyarakat dengan Kepalo nan Duo Puluh (Kepala Yang Dua Puluh atau Dua Puluh Kepala) yang merupakan kombinasi dari ke-19 orang pilihan dari Koto Rayo yang masih hidup tersebut dan ditambahkan dengan seperangkat perlengkapan obat-obatan tradisonal berupa sirih, kapur dan lain sebagainya sehingga mencapai dua puluh seperti jumlah orang pilihan yang dikirim ke muara sungai dan terlibat peperangan itu.

Di masa-masa kolonial Belanda dan Jepang serta hingga beberapa tahun belakangan ini, terdapat banyak cerita yang menyelimuti kemisteriusan Koto Rayo. Di antaranya, adanya beberapa gadis yang sebenarnya bersama-sama dengan manusia lainnya mendayung sampan (biduk dalam bahasa setempat) dari hilir menuju hulu sungai, tetapi ketika sampai di Koto Rayo langsung menghilang secara misterius. Kawasan ini di masa lalu juga dijadikan beberapa oknum masyarakat untuk mencari pesugihan atau meminta kekayaan secara gaib dan beragam permintaan lainnya. Hal ini terutama dilakukan terhadap kuburan yang dianggap keramat oleh masyarakat setempat. Di samping itu, beberapa orang diberitakan hilang atau tersesat di kawasan ini dan tidak pernah dapat ditemukan karena bermaksud jahat serta lain sebagainya.

\section{Kontekstualisasi 'Koto Rayo', Upaya Mempertemukan Cerita Rakyat dengan Catatan Sejarah}

Beragam cerita rakyat tersebut tidak jarang mengandung sejarah yang bertautan dengan kejadian sesungguhnya yang pernah ada di masa itu. Akan tetapi karena fungsi utamanya sebagai pengetahuan lokal yang dibangun atas model pemikiran yang berkembang di masa itu, maka 'sejarah' yang mengemuka adalah cerita yang disertai aroma mistis, gaib dan penambahan di sana sini seperti yang ada pada Koto Rayo ini. Hal ini jika mendasarkan pada pendapat Auguste Comte (1798-1857), seorang ilmuan sosial terkemuka asal Prancis yang juga dianggap sebagai penemu fisika sosial yang pada tahun 1839 diganti menjadi sosiologi. Menurut Comte, perkembangan pemikiran manusia terbagi atau melalui tiga tahapan (fase), yaitu: teologi atau fiktif; metafisik atau abstrak; dan ilmiah atau positif. Pada fase teologi, pemikiran manusia menganggap bahwa semua gejala dihasilkan oleh tindakan langsung dari hal-hal yang supernatural dan berlangsung pada era sebelum 1300. Sedangkan fase kedua (metafisik) berlangsung pada era 1300-1800 yang ditandai dengan pemikiran manusia yang menganggap bahwa semua gejala bukan berasal dari hal-hal yang supernatural seperti pada tahapan pertama, tetapi berasal dari kekuatan-kekuatan abstrak. Terakhir, fase ilmiah yang berlangsung sejak era 1800 yang ditandai dengan model pemikiran manusia yang berlandaskan pada penalaran dan pengamatan yang kelak memunculkan pengetahuan ilmiah. Berdasarkan hal ini, maka bisa jadi munculnya beragam cerita rakyat seperti Koto Rayo ini terjadi pada kedua fase yang disebutkan oleh Comte di atas ( Ritzer \& Goodman, 2004: 16-20, Johnson, 1988: 84-86, Jary, 1991: 107-109, Abercrombie, 2006: 104). 
Kenapa penulis sampai pada kesimpulan demikian? Hal ini tidak lain karena berdasarkan penulusuran terhadap beberapa sumber yang mengetengahkan sejarah mengenai Jambi di masa lalu ternyata memiliki keterkaitan dengan cerita masyarakat mengenai Koto Rayo, ditambah lagi dengan adanya sisa-sisa bangunan yang mungkin adalah candi berupa batu bata merah. Sebagaimana disebutkan sebelumnya bahwa di Koto Rayo berdiri sebuah pemukiman atau kerajaan kecil yang menguasai daerah sekitarnya di saat wilayah Jambi pada umumnya saat itu tengah dalam keadaan kacau. Cerita rakyat yang mengiringi perjalanan Koto Rayo memang tidak menyebutkan tahunnya, akan tetapi berdasarkan keterangan kondisi saat itu yang tengah kacau dan pengiriman 19 orang terpilih untuk memantau kondisi di muara sungai, maka dapat dikatakan bahwa saat itu adalah masa Kerajaan Melayu Kuno pada abad ke-3 sampai abad ke-5 Masehi, atau Kerajaan Melayu Jambi pada tahun 644/645 Masehi atau Kerajaan Sriwijaya pada tahun 670 Masehi (Muljana, 2008).

Berdasarkan catatan sejarah yang mengiringi beragam kekuatan yang pernah ada di wilayah Jambi, hampir seluruh kekuatan yang ada dalam setiap masanya selalu menempatkan wilayah ini sebagai prioritas untuk dijadikan daerah kekuasaannya. Hal ini dapat dimengerti karena posisi wilayah Jambi yang strategis, terutama dari aspek aksesibilitas pelayaran untuk transportasi dan perdagangan yang menjadikan sungai sebagai sarana utamanya. Meskipun sama-sama memiliki sumberdaya (resource) sungai, baik yang besar maupun yang kecil, namun posisi Jambi lebih strategis dibandingkan wilayah-wilayah lainnya di Sumatra. Kenyataan ini dimungkinkan karena posisi Jambi yang langsung berhadapan dengan laut lepas dan dekat dengan jalur utama perdagangan saat itu, bahkan hingga saat ini, Selat Malaka. Ini pula yang membuat Prof. Slamet Muljana dan beberapa ilmuan lainnya lebih cenderung berkesimpulan bahwa Jambi adalah pusat Kerajaan Sriwijaya dibandingkan Palembang yang 'diakui' secara resmi hingga saat ini. Oleh karena itu, beragam kekuatan yang membentuk kerajaan muncul di wilayah Jambi, dimana catatan sejarah memulainya dengan adanya Koying, Tupo dan Kantoli dalam periode Melayu Kuno di abad ke-3 sampai abad ke-5 Masehi.

Karena posisi strategisnya di atas, beragam kekuatan tentu bersaing untuk dapat menjadi penguasa wilayah ini. Tentunya tidak jarang persaingan-persaingan tersebut menimbulkan peperangan dan satu kekuatan yang kalah akan digantikan oleh kekuatan lainnya yang berhasil memenangkan peperangan tersebut. Kerajaan Koying dikalahkan oleh dominasi Kerajaan Tupo di abad ke-3 Masehi dan berhasil menguasai Jambi selama sekitar dua ratus tahun sampai kemudian dikalahkan oleh kekuatan baru di wilayah tersebut, Kerajaan Kantoli. Ternyata Kantoli juga tidak lama berkuasa di Jambi karena kemudian muncul kekuatan lainnya yang juga ingin menguasai wilayah ini, yaitu Kerajaan Melayu Jambi pada abad ke-6 Masehi. Seperti halnya Kantoli yang harus menyerah pada lawannya, Melayu Jambi juga harus mengakui kekuatan berikutnya yang tak kalah dahsyatnya, Kerajaan Sriwijaya di abad yang sama dalam kisaran 70 tahun saja.

Beragam persaingan yang berakibat pada peperangan dan berujung pada pergantian kekuasaan tentu tidak menumpas habis kekuatan yang ada sebelumnya. Ada sisa kekuatan dalam skala kecil yang lebih memilih menyingkir atau melarikan diri atau menjauh dan mencoba membangun kekuatan di wilayah-wilayah terpencil yang biasanya di pedalaman yang sulit dijangkau musuh. Hal seperti inilah yang mungkin terjadi dengan Koto Rayo, yaitu sisa-sisa kekuatan yang dikalahkan oleh musuhnya dan melarikan diri serta membangun kekuatan di pedalaman Jambi. Fenomena ini misalnya mengemuka dengan pengiriman 20 orang terpilih dari Koto Rayo untuk memantau keadaan atau kondisi di muara Sungai Tabir atau di hulu dari Sungai Batanghari yang langsung menuju Jambi sebagai pusat kekuasaan kerajaan. Ditambahkan lagi dengan cerita menghilangnya para penghuni Koto Rayo setelah menganggap ke-20 orang yang diutus untuk memantau keadaan tersebut sudah meninggal dunia atau terbunuh oleh musuh. Meskipun demikian, karena ketiadaan petunjuk tahun yang menyebutkan kapan peristiwa 
tersebut terjadi, maka yang terjadi adalah memperbandingkan sisa-sisa peninggalan mereka dengan yang ada di tempat lainnya. Batu-batu bata merah yang banyak berserakan di bekas pemukiman Koto Rayo mungkin dapat memberi petunjuk kapan persisnya situs ini berlangsung. Sebagaimana disebutkan sebelumnya bahwa menurut pengamatan sepintas penulis terdapat persamaan antara batu bata merah Koto Rayo dengan batu merah untuk membangun Candi Muaro Jambi. Berarti, berdasarkan hal ini maka dapat disimpulkan bahwa ada kedekatan sejarah antara Koto Rayo dengan Candi Muaro Jambi. Jika demikian, maka dapat dikatakan situs Koto Rayo hampir satu masa dengan Candi Muaro Jambi dan orang-orang Koto Rayo mungkin adalah para pelarian atau sisa-sisa kekuatan dari Kerajaan Melayu Jambi yang ditaklukkan Kerajaan Sriwijaya pada abad ke-6 Masehi. Sementara batu-batu bata merah yang diyakini merupakan bekas bangunan candi sudah ada sebelum terjadinya peristiwa pelarian tersebut karena wilayah ini termasuk daerah kekuasaan kerajaan-kerajaan yang pernah menguasai Jambi, termasuk Kerajaan Melayu Jambi. Bagaimana dengan ke-20 orang yang dikirim ke muara sungai tersebut? Karena ketiadaan informasi mengenai asal usul mereka, maka ada beberapa asumsi yang mungkin dapat menjawabnya. Ke-20 orang Koto Rayo tersebut bisa jadi adalah para perwira kerajaan di Jambi yang melarikan ke Koto Rayo dan menjadi tulang punggung utama Koto Rayo. Atau, bisa juga mereka adalah orang-orang asli Koto Rayo yang dikombinasikan dengan para perwira pelarian dari kerajaan di Jambi.

Fakta lainnya yang semakin menguatkan asumsi penulis bahwa orang-orang Koto Rayo adalah pelarian kerajaan di Jambi adalah pemilihan posisi dan letak situs ini yang strategis. Dari aspek pertahanan militer yang mungkin ada saat itu, posisi Koto Rayo sangat menguntungkan untuk memantau keadaan sekitarnya dari kemungkinan serangan musuh. Terletak di atas sebuah bukit yang agak bertingkat, berada persis di tikungan dari aliran Sungai Tabir yang membentuk huruf $L$ (letter $L$ ) dan dari posisinya ini orang-orang Koto Rayo dapat memandang lurus ke arah timur sepanjang aliran sungai sejauh sekitar satu kilometer. Jika ada armada militer musuh yang menggunakan kapal dan perahu dari arah timur (Jambi) maka akan segera dapat diketahui oleh orang-orang yang ada di Koto Rayo. Dengan mengetahui keberadaan musuh sedini mungkin, maka persiapan-persiapan menghadapi serbuan akan dapat dilakukan seefektif mungkin. Bandingkan misalnya jika lokasi Koto Rayo berada di balik tikungan sungai, meskipun keberadaannya terlindung dari pandangan tetapi tidak dapat segera mengetahui posisi musuh.

\section{Koto Rayo dan Kearifan Lokal}

Cerita rakyat, bagi beberapa pihak, yang banyak terdapat dalam masyarakat adalah dongeng yang diwariskan secara turun temurun dan disampaikan secara lisan tanpa dapat dibuktikan secara ilmiah. Misalnya, cerita tentang terbentuknya Danau Toba, cerita dibalik terpisahnya Pulau Sumatra dan Pulau Jawa yang kini dikenal dengan Selat Sunda dan beragam cerita rakyat yang mengungkapkan kejadiankejadian dibalik terjadinya sesuatu. Namun demikian, jika mencermati di balik beragam cerita tersebut maka akan didapatkan pelajaran hidup yang sebenarnya sangat berarti bagi generasi berikutnya. Ceritacerita tersebut sesungguhnya, seringkali, hendak mengingatkan manusia akan sebuah pelajaran berarti terhadap sesuatu, baik dalam hubungan manusia dengan alam maupun antara sesamanya, yang kemudian mewujud dalam ilmu pengetahuan modern dengan kearifan lokal (local knowledge), yaitu pengetahuan kebudayaan yang dimiliki oleh masyarakat tertentu yang mencakup di dalamnya sejumlah pengetahuan kebudayaan yang berkaitan dengan model-model pemanfaatan dan pengelolaan sumberdaya alam secara lestari (Zakaria, 1994).

Cerita Koto Rayo mengisahkan suatu tempat yang dulu pernah didiami oleh orang-orang yang 'mungkin' diidentifikasikan sebagai para pelarian dari kerajaan di Jambi yang ditaklukkan oleh para musuhnya. Mereka menempati sebuah kawasan yang terletak di atas sebuah bukit pinggiran sungai yang di dalamnya kini ditemukan batu bata merah yang berserakan dan 
beberapa kubur tua. Banyak cerita misterius dan supranatural seputar situs purbakala ini, seperti menghilangnya para penghuninya secara tidak diketahui; tersesatnya beberapa orang dalam kawasan ini; penampakan beberapa gadis secara misterius; pohon-pohon di dalamnya yang tidak dapat ditebangi oleh peralatan modern dan lain sebagainya. Itulah cerita yang berkembang dalam masyarakat mengenai lokasi yang dikatakan sebagai tempat asal orang-orang yang ada di wilayah tersebut.

Dari aspek kajian budaya, cerita Koto Rayo dapat dikategorikan sebagai kearifan lokal yang dimiliki oleh masyarakat yang ada di daerah tersebut. Nilai-nilai budaya yang diwariskan oleh para pendahulu mereka yang diharapkan dapat diwariskan kepada generasi-generasi mendatang. Nilai-nilai budaya yang berkaitan dengan pelestarian lingkungan hidup, khususnya sumberdaya alam (nature resources).

Sebagaimana diketahui bahwa hutan dan sungai menjadi sumberdaya utama yang ada di daerah ini, dan Jambi pada umumnya. Kedua sumberdaya alam ini menjadi bagian integral dalam kehidupan masyarakat karena sungai dan hutan sangat berkaitan erat dengan orangorang yang ada di wilayah ini. Sungai menjadi transportasi utama, sebelum sarana transportasi darat berkembang pesat seperti saat ini, untuk mobilitas masyarakat dari satu tempat ke tempat lainnya. Di samping itu, sungai juga menyimpan resources lainnya yang tak kalah pentingnya bagi kehidupan masyarakat, yaitu ikan, pasir dan batu. Sungai juga menjadi tempat masyarakat melakukan aktivitas sehari-hari seperti mencuci, kakus dan mandi, sebelum di rumah-rumah mereka memiliki sarana-sarana tersebut seperti saat ini. Begitu juga halnya dengan hutan yang menjadi tempat masyarakat mencari kayu untuk keperluan membuat rumah dan lain sebagainya, mencari damar untuk penerangan saat listrik belum ada seperti saat ini dan berburu beragam jenis binatang untuk keperluan sehari-hari masyarakat.

Berangkat dari hal di atas, cerita Koto Rayo dapat dipahami sebagai cerita mengenai pelestarian sumberdaya alam yang diperlukan dan menjadi bagian integral kehidupan masyarakat. Agar menjadi efektif, maka dimunculkanlah beragam cerita mistis agar orang-orang tidak sembarangan memasuki apalagi melakukan aktivitas perusakan. Areal Koto Rayo yang sebenarnya berupa hutan yang cukup lebat dimaksudkan untuk menjaga kelestarian hutan dan sungai yang ada di dalamnya. Meskipun demikian, seiring dengan kian lemahnya kesadaran budaya dan lingkungan serta intensitas perekonomian yang kian maju pesat, maka lambat laut areal 'larangan' Koto Rayo kian menyusut. Jika dahulu wilayah 'misterius' ini mencakup daerah yang luas, sekitar puluhan hektare, tetapi kini hanya tersisa hanya kurang dari satu hektare saja. Sebagian besar wilayahnya telah berubah wujud menjadi perkebunan karet dan kelapa sawit masyarakat sekitar. Saat ini lokasi yang 'disisakan' praktis hanya di tempat yang dikatakan sebagai pusat Koto Rayo, yaitu areal kuburan, tempat banyak batu bata berserakan dan tepi sungai. Sungguh ironis, kesadaran budaya dan lingkungan yang lemah harus berhadapan dengan ekspansi ekonomi yang terus menggurita.

\section{Penutup}

Secara umum, keberadaan Koto Rayo dalam sejarah Jambi di masa lalu memang masih misterius. Akan tetapi, terdapat beberapa hal yang berkaitan dan bertautan dengan catatan sejarah yang pernah ditulis mengenai wilayah ini. Hal ini terutama menyangkut kondisi yang ada di masa itu yang memiliki kesamaan dan sisa-sisa peninggalan mereka berupa batu-batu bata yang kemungkinan besar adalah bangunan candi. Lebih dari itu masih sangat misterius, semisterius beragam cerita yang mengiringi perjalanan Koto Rayo yang berkembang dan beredar di tengah masyarakat. Bagaimana pun juga, Jambi menyimpan beragam sejarah masa lampau yang sangat banyak karena menjadi pusat kekuasaan beragam kekuatan di masa lalu. Sebagian besar bukti sejarah tersebut, saya yakin, masih terkubur di tanah yang kini menjadi areal berjuta-juta hektar perkebunan karet dan kelapa sawit. 
Sistem pertanian di Jambi, dan Sumatra umumnya, memang sedikit banyak turut andil dalam menyebabkan minimnya penemuan benda-benda sejarah masa lampau wilayah ini. Jambi yang mengenal sistem pertanian tanaman keras berupa ladang yang menanam karet dan kelapa wasit tentu sangat susah menemukan benda-benda sejarah yang umumnya terkubur di dalam tanah. Bandingkan dengan Jawa yang menggunakan sawah sebagai model pertanian utamanya, dengan mencakul tanah seringkali masyarakat menemukan beragam peninggalan sejarah. Hal ini misalnya banyak terjadi di Kediri, Trowulan Mojokerto, Yogyakarta dan lainnya sebagainya. Di samping itu, tenaga ahli arkeologi, antropologi dan ilmu-ilmu yang berkaitan dengan kepurbakalaan juga masih minim di Jambi, terutama yang berasal dari masayarakat setempat. Masyarakat sepertinya lebih cenderung mengarahkan anak-anaknya untuk menempuh pendidikan yang dianggap lebih prospektif bagi masa depannya, seperti ekonomi dan kedokteran. Implikasinya adalah minimnya aktivitas pengungkapan sejarah masa lampau akibat kurangnya penemuan-penemuan benda-benda bersejarah.

\section{Daftar Pustaka}

Abercrombie, Nicholas dkk. 2006. Kamus Sosiologi. Yogyakarta: Pustaka Pelajar.

Johnson, Doyle Paul. 1988. Teori Sosiologi Klasik dan Modern. Jakarta: PT. Gramedia Pustaka Utama.

Jary, David. \& Julia Jary. 1991. Collins Dictionary of Sociology. Glasgow: HarperCollins Publishers.

Locher-Scholten, E.B. 2002. "Berdirinya Kekuasaan Kolonial di Jambi: Partai Ganda Politik dan Ekonomi” dalam J. Thomas Lindblad (ed.), Fondasi Historis Ekonomi Indonesia. Yogyakarta: Pusat Studi Asia Tenggara Universitas Gadjah Mada-Pustaka Pelajar.

Muljana, Slamet. 2008. Sriwijaya. Yogyakarta: LKiS.

Ritzer, George \& Douglas J. Goodman. 2004. Teori Sosiologi Modern. Jakarta: Kencana.

www.wikipediaindonesia.com/kerajaan-melayu-jambi. Akses tanggal 5 Maret 2011.

www.melayuonline.com/kerajaan-melayu-jambi. Akses tanggal 5 Maret 2011.

Zakaria, Y.R. 1994. Hutan dan Kesejahteraan Masyarakat. Jakarta: Penerbit Walhi. 


\section{Lampiran:}

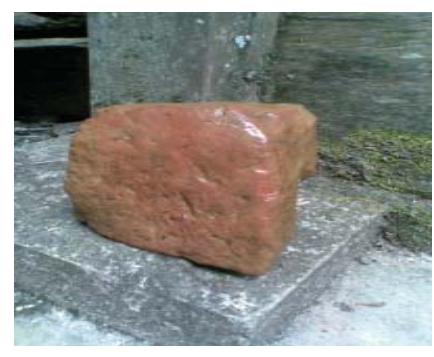

Contoh Batu Bata Merah Koto Rayo

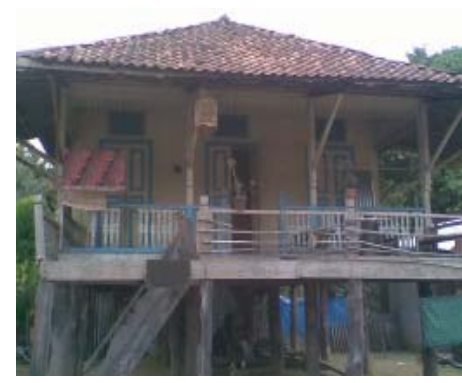

Rumah Kuno Yang Masih Tersisa

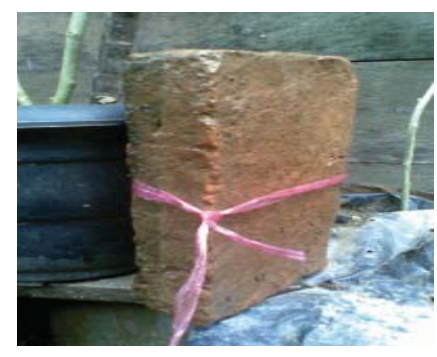

Contoh Batu Bata Merah Candi Muara Jambi

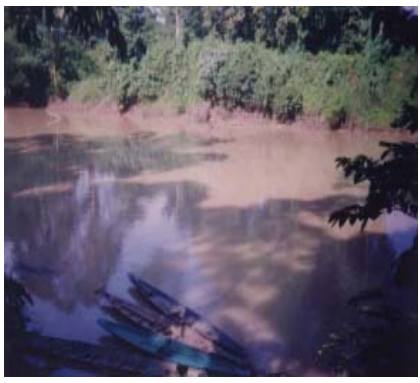

Sungai Tabir

Penulis berasal dari Jambi dan menempuh pendidikan pascasarjana di Program Pascasarjana Sosiologi Universitas Gadjah Mada Yogyakarta. Pernah bekerja sebagai Sekretaris Rektor dan Pembimbing Kemahasiswaan di Universitas Proklamasi 45 Yogyakarta (2009-2010) dan Ahli Sosiologi Masyarakat pada PT. Gama Konsulindo Malang untuk proyek Rencana Pembangunan Jangka Panjang (RPJP) Kota Surabaya Tahun 2010-2025. Saat ini bekerja sebagai Surveyor Sosial di Sidoarjo Jawa Timur bekerjasama dengan PT. Perusahaan Gas Negara (PGN) Regional II Jawa Timur Surabaya dan Peneliti Sosial Mandiri di berbagai wilayah di Jawa Timur, Jawa Tengah, Yogyakarta dan Jambi.

Tinggal di Jalan Wuluh 8F Papringan Yogyakarta 55281. Nomor Handphone: 085228672292 (AS) \& 087839885015 (xl). Alamat e-mail: roedy78@yahoo.co.id. Web blog: http://roedijambi.wordpress.com. 